\title{
Formation of the 42-mer Amyloid $\beta$ Radical and the Therapeutic Role of Superoxide Dismutase in Alzheimer's Disease
}

\author{
Kazuma Murakami, ${ }^{1}$ Takahiko Shimizu, ${ }^{2}$ and Kazuhiro Irie ${ }^{1}$ \\ ${ }^{1}$ Laboratory of Organic Chemistry in Life Science, Division of Food Science and Biotechnology, Graduate School of Agriculture, \\ Kyoto University, Sakyo-ku, Kyoto 606-8502, Japan \\ ${ }^{2}$ Molecular Gerontology, Tokyo Metropolitan Institute of Gerontology, Itabashi-ku, Tokyo 173-0015, Japan \\ Correspondence should be addressed to Kazuma Murakami, alzkazu@kais.kyoto-u.ac.jp
}

Received 29 October 2010; Accepted 16 December 2010

Academic Editor: Gal Bitan

Copyright (C) 2011 Kazuma Murakami et al. This is an open access article distributed under the Creative Commons Attribution License, which permits unrestricted use, distribution, and reproduction in any medium, provided the original work is properly cited.

Oxidative stress is closely involved in age-related diseases and ageing itself. There is evidence of the leading contribution of oxidative damage to neurodegenerative disease, in contrast to other diseases where oxidative stress plays a secondary role. The 42 -mer amyloid $\beta(\mathrm{A} \beta 42)$ peptide is thought to be a culprit in the pathogenesis of Alzheimer's disease (AD). A $\beta 42$ aggregates form the oligomeric assembly and show neurotoxicity, causing synaptic dysfunction. A $\beta 42$ also induces tissue oxidation (DNA/RNA, proteins, and lipids) through trace metals ( $\mathrm{Cu}, \mathrm{Zn}$, and $\mathrm{Fe}$ ), which can be protected by antioxidant enzymes, vitamin $\mathrm{C}$, and vitamin E. Superoxide dismutase catalyzes the conversion of toxic superoxide radical to less reactive hydrogen peroxide, contributing to protection from AD. Here we review the involvement of oxidative stress in AD progression induced from an imbalance between the radical formation of $\mathrm{A} \beta 42$ itself together with unique turn structure at positions Glu22 and Asp23 and several defense systems.

\section{Oxidative Stress in Ageing-The Involvement of Superoxide Radical}

Oxidative stress caused by reactive oxygen species (ROS) has been implicated in numerous age-related diseases and ageing itself $[1,2]$. ROS include superoxide anions, hydrogen peroxide, hydroxyl radicals, and singlet oxygen. ROS are also involved in neurodegeneration such as Alzheimer's disease (AD), Parkinson's disease, and amyotrophic lateral sclerosis, because the brain is one of the most vulnerable tissues in the body to oxidative injuries based on its high rate of oxygen consumption [3]. The hydroxyl radical is believed to be one of the main stimuli of oxidative damage (Figure 1) and reacts with several biomolecules, leading to the formation of 8-hydroxydeoxyguanosine (8-OHdG)/8-hydroxyguanosine (8-OHG) in DNA/RNA, the formation of methionine sulfoxide, carbonylation in proteins, and lipid peroxidation. In particular, lipid peroxidation can lead to the production of 4-hydroxyl nonenal (4-HNE), malondialdehyde (MDA), and thiobarbituric acid-reacting substances (TBARS) as byproducts. The subsequent processes to hydroxyl radical could be involved in peroxynitrite formation by stimulating inducible nitric oxide synthase (i-NOS). Hydrogen peroxide $\left(\mathrm{H}_{2} \mathrm{O}_{2}\right)$ is less reactive but is involved in the Fenton reaction (HaberWeiss procedure, Figure 1), providing the hydroxyl radical.

On the other hand, the superoxide radical is also biologically toxic, especially under the condition of radicalradical reactions which could occur at a diffusion-controlled rate. It presents widely in high quantity. A small fraction $(0.4 \%-4 \%)$ of oxygen utilized in the mitochondria is reduced by single electron transfer during the initial step of the electron transport chain, followed by the generation of superoxide radical [4]. Catalase and peroxidases (such as glutathione peroxidase: $\mathrm{GPx}$ ), which exists in ubiquitous tissues, can eliminate $\mathrm{H}_{2} \mathrm{O}_{2}$ generated from superoxide radicals (Figure 1 ).

Superoxide dismutases (SODs) are the main antioxidant enzymes that convert superoxide anions to $\mathrm{H}_{2} \mathrm{O}_{2}$, protecting cells and tissues from ROS generated from endogenous and exogenous sources [5]. SODs consist of three types of isoforms expressed in mammalian cells: copper/zinc SOD (CuZn-SOD, SOD1), which is located in the cytoplasm, 


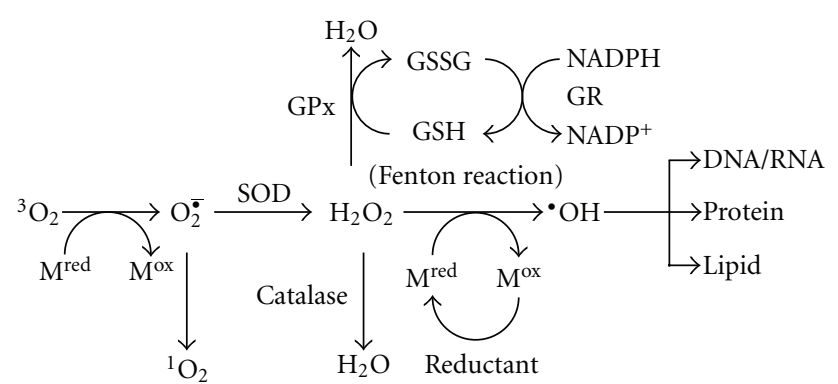

FIGURE 1: Generation of reactive oxygen species and defense systems in the cell. $\mathrm{M}^{\text {red }}$ or $\mathrm{M}^{\mathrm{ox}}$, reduced or oxidized form of metals; SOD, superoxide dismutase; GSH, reduced glutathione; GSSG, oxidized glutathione; GR, glutathione reductase; GPx, glutathione peroxidase; NADPH or $\mathrm{NADP}^{+}$, reduced or oxidized nicotinamide adenine dinucleotide phosphate; VC, vitamin C; VE, vitamin E.

manganese SOD (Mn-SOD, SOD2), which exists in the mitochondrial matrix, and extracellular SOD (EC-SOD, SOD3), which is also a complex of CuZn. Some CuZn-SOD is also seen in the intermembrane space of mitochondria [6].

Van Remmen is one of the most influential leaders in ageing research. She and her colleagues have reported several ageing symptoms of hepatic carcinoma [7] and muscle atrophy [8] in CuZn-SOD knockout mice. They also studied the physiological role of several antioxidant enzymes in longevity using gene-disrupting mice [9]. Notably, CuZnSOD-deficient mice showed the multiple pathologies in several tissues with decreased lifespan compared to wildtype mice. Fujii and colleagues also indicated that hemolytic anemia was triggered by autoantibody production in $\mathrm{CuZn-}$ SOD-deficient mice [10].

Our group has reported that CuZn-SOD-deficient mice showed skin thinning [11] as well as increased drusen formation, which is a typical characteristic of age-related macular degeneration as neurodegeneration [12] and fatty liver [13]. Taken together, these observations demonstrate that CuZn-SOD knockout mice have the potential to be a valuable animal model for investigating human ageing. On the other hand, Shimizu and colleagues generated various tissue-specific Mn-SOD conditional knockout mice using a Cre-loxp system because total knockout of Mn-SOD induces neonatal lethality in mice $[14,15]$, liver-specific MnSOD knockout mice which show no obvious morphological abnormalities or biochemical changes in the liver [16], heart/muscle-specific Mn-SOD-deficient mice which exhibit dilated cardiomyopathy with the downregulation of specific biomolecules in the mitochondria [17], and skeletal musclespecific Mn-SOD knockout mice which develop severe disturbance of exercise activity without muscle atrophy [18]. Furthermore, they found severe phenotypes in the brains of brain-specific Mn-SOD-deficient mice showing a spongiform encephalopathy-like pathology associated with gliosis [19]. The most abundant ROS within cells influencing synaptic plasticity, memory function, and neuronal death is considered to be the superoxide radical [20]; this suggests that SOD plays a protective role in neurodegeneration.
We introduce the relevance of oxidative stress to $\mathrm{AD}$ in the following section.

\section{A $\beta$ Theory in Alzheimer's Disease}

$\mathrm{AD}$ is generally characterized by the aggregation of amyloid $\beta(\mathrm{A} \beta)$ in senile plaques. $\mathrm{A} \beta$ mainly consists of 40 - and 42 -residue amyloid $\beta$ peptides $(\mathrm{A} \beta 40, \mathrm{~A} \beta 42)$, secreted from amyloid precursor protein (APP) by two proteases $(\beta$ - and $\gamma$-secretases) $[21,22]$. A $\beta 42$ plays a more critical role in the pathogenesis of $A D$ than $A \beta 40$ because $A \beta 42$ aggregates more extensively to form fibrils and shows stronger neurotoxicity [23]. On the other hand, there is increasing evidence that the oligomeric assembly of $\mathrm{A} \beta$ could induce memory decline and synaptotoxicity in $\mathrm{AD}$ [24], while mature plaques were reported to be nontoxic $[25,26]$ and to serve as a store of the toxic assembly of $\mathrm{A} \beta$ [27].

Studies on several kinds of $\mathrm{A} \beta$ oligomer associated with neurotoxicity or synaptotoxicity have been accumulated. Recently, Teplow and colleagues summarized and overviewed $\mathrm{A} \beta$ assembly [28]: paranucleus, protofibrils (24-700 mer) [29], A $\beta$-derived diffusible ligands (ADDL, $~ 53 \mathrm{kDa}$ ) [30], $\mathrm{A} \beta * 56(\sim 56 \mathrm{kDa}, 12$-mer $)$ [31], amylospheroid $(\sim 150-$ $700 \mathrm{kDa})[32], \mathrm{A} \beta \mathrm{O}$ ( $90 \mathrm{kDa}, 15-20 \mathrm{mer})$, annulus (150$250 \mathrm{kDa})$, and $\beta$ amyball. Selkoe and colleagues suggested that $\mathrm{A} \beta$ dimers are the smallest synaptotoxic species and that plaque cores are largely inactive but sequester or release dimers [33]. They developed unique oligomer specificELISA using 82E1 antibody, whose epitope is N-terminal, for both antigen capture and detection, to reveal a clear correlation of the oligomer levels in the plasma and brain extracts with various cognitive levels of $\mathrm{AD}$ patients [34]. Oligomeric molecules of $\mathrm{A} \beta$ are believed to consist of 2 or $3 \mathrm{x} n$-multimers based on the dimer or trimer, respectively. To elucidate the mechanism of $\mathrm{A} \beta$ oligomerization, many scientists have developed a method or detection tools. Bitan and colleagues created a method of the photoinduced crosslinking of unmodified proteins to prepare the oligomers in large quantity [35]. Glabe and colleagues generated a conformation-dependent antibody (A11 clone) against $\mathrm{A} \beta$ oligomers, which does not recognize fibrils and also reacts with other types of amyloid oligomers, such as $\alpha$-synuclein in Parkinson's disease, polyglutamine in Huntington's disease, and prion peptide 106-126 in prion disease [36]. Recently, they reported the fibril-specific, conformation-dependent antibody (OC clone), recognizing soluble oligomers ranging from a dimer to greater than $250 \mathrm{kDa}$ [37].

\section{Role of Trace Metals and Formation of A $\beta$ Radical in Alzheimer's Disease}

In 1965, Terry and Pena. first reported the relevance of aluminum to the pathology of AD; they injected aluminum salts into the rabbit brain, resulting in neurofibrillary tangle formation [38], which is another hallmark of AD. Although aluminum in the diet or drinking water had been long believed as a risk factor for AD [39], Ehmann et al. in 1986 showed that this hypothesis for AD was an artifact [40]. 
It is known that transition metals, such as $\mathrm{Cu}, \mathrm{Zn}$, and $\mathrm{Fe}$, are enriched in senile plaques [41]. $\mathrm{A} \beta$ causes protein oxidation, DNA/RNA oxidation, and lipid peroxidation in vitro and in vivo, possibly by aggregating to generate radicals via a trace of metal ions ( $\mathrm{Cu}$ and $\mathrm{Zn}$ ) [41-44]. The imbalance of copper homeostasis is also implicated in the etiology of $\mathrm{AD}$ [45]. The neurotoxic effects of $\mathrm{A} \beta 42$ and $\mathrm{A} \beta 40$ in cell culture correlate with the ability to reduce $\mathrm{Cu}(\mathrm{II})$ to $\mathrm{Cu}(\mathrm{I})$ and to generate $\mathrm{H}_{2} \mathrm{O}_{2}$ in a cell-free system [46]. The direct interaction of metals with $\mathrm{A} \beta$ in the N-terminal region is essential for its aggregation and neurotoxicity. In complex formation with $\mathrm{Cu}(\mathrm{II})[47,48]$, each of the three histidine residues at positions 6,13 , and 14 of $A \beta 42$, Tyr 10 [46, 49-52], and Asp1/Asp7 [53] may be involved. Recent ESR studies by Drew et al. suggested that the Ala2 carbonyl could be involved in the $\mathrm{Cu}(\mathrm{II})$ coordination [54]. Tyr10 is easily oxidized to the tyrosyl radical by $\mathrm{Cu}(\mathrm{II})$, leading to the production of $\mathrm{H}_{2} \mathrm{O}_{2}$ [55]. Quite recently, Ono et al. reported that UK (H6R) and Tottori (D7N) mutations in the $\mathrm{N}$-terminal regions accelerated the ability to form oligomers and enhanced cytotoxicity [56]. These mutations might change the binding mode of metal with $\mathrm{A} \beta$ peptides, resulting in the increased ability to form toxic oligomers.

Based on the metal etiology in $\mathrm{AD}$, therapeutics using metal chelators might be promising to prevent plaque formation by extracting the metals. Bush and colleagues treated an APP transgenic mouse with a CuZn chelator, clioquinol (8-hydroxy quinoline), showing the effective removal of plaque depositions [57]; however, it might alter the homeostasis of copper and counteract the intracellular copper-depleting effects of APP in initial clinical trials of the treatment of AD [58]. Eventually, it was removed from the market by FDA due to difficulties associated with chelation of $\mathrm{Co}$ (II) involved in vitamin B12. They also mentioned that the problems were also due to the large magnitude difference in affinity of $\mathrm{Cu}(\mathrm{II})$ between clioquinol and $\mathrm{A} \beta 42$, in which $K_{\mathrm{d}}$ of $\mathrm{Cu}(\mathrm{II})$ for clioquinol and $\mathrm{A} \beta 42$ are nanomolar and attomolar, respectively [59]. Other processes for plaque removal by clioquinol could be involved. Recently, they advanced the chelating strategy into the second-generation clioquinol analogue, PBT2, which outperformed clioquinol by markedly decreasing soluble interstitial $\mathrm{A} \beta$ and rescuing cognitive impairment [60]. PBT2 was already found to reverse frontal lobe functional deficits and to decrease $A \beta 42$ in a phase IIa clinical trial [61].

Butterfield and colleagues pioneered the contribution of Met35 to the neurotoxicity and oxidative effects of $A \beta$ $[44,62]$. The oxidized form of Met35 was detected both in the brains of AD patients [63] and the APP transgenic mouse model [64]. They suggested the reactive form of Met35 in A 342 as an S-oxidized radical cation, abstracting an allylic hydrogen of phospholipid acyl chains to give allyl radicals, followed by lipid peroxidation [43]. The methionine sulfoxide reductase is known to reverse methionine oxidation. Moskovitz and colleagues reported that a knockout mouse of one isoform of this enzyme caused enhanced neurodegeneration in the brain hippocampus, implying that the oxidation of Met residue plays a role in brain pathology [65]. The S-oxidized radical cation in Met35 is generally too unstable to cause oxidative damage continuously [66]. A stabilization mechanism for long-lasting oxidative stress in $\mathrm{AD}$ progression is required. We have proposed the emerging role of the turn formation at Glu22 and Asp23 in the pathogenesis of $\mathrm{AD}[67,68]$ and its contribution to oligomer formation [69] following intracellular amyloidgenesis [70]. Our continuous studies using a systematic proline replacement, solid-state NMR, and ESR have elucidated A $\beta 42-$ mediated neurotoxicity in vitro; the central turn formation could bring Tyr10 radical generated through trace metals accompanied by the generation of $\mathrm{H}_{2} \mathrm{O}_{2}$, which are moved close to Met35, resulting in the production of the Soxidized radical cation (Figure 2(a)). The systematic proline replacement of $\mathrm{A} \beta 42$ proposed that not only the turn formation at Glu22 and Asp23 but the turn at Gly38 and Val39 increases aggregation and neurotoxicity [71]. This additional C-terminal turn could enable the carboxylate anion at Ala42 to interact with the S-oxidized radical cation by forming $\mathrm{S}-\mathrm{O}$ bonding through an intramolecular $\beta$-sheet at positions 35-37 and 40-42 (Figure 2(a)). The resultant hydrophobic core in the C-terminus would enhance $A \beta 42$ aggregation, sequestering or releasing the radical species for long-lasting oxidative stress in $\mathrm{AD}$. If considered for the lower toxicity of A $\beta 40$ toxicity, the $S$-oxidized radical cation of Met35 might not be fully stabilized by the incomplete association of Met35 radical with the carboxylate anion at Val40 (Figure 2(a)) or by the labile electrostatic interaction between the sulfur atom of Met35 and the amide carbonyl group of Ile31 under the condition of $\alpha$-helix formation in the C-terminal region [72]. Collectively, the formation of toxic $\mathrm{A} \beta$ radicals generated through trace metals could induce the malfunction of signal transduction pathways after the interaction with membranes. This mechanism (Figure 2(a)) can in part explain why $\mathrm{A} \beta 42$ is more neurotoxic than $A \beta 40$ [73]. The following generation of superoxide radical and hydroxyl radical occasionally accompanied with the stabilization of $\mathrm{A} \beta 42$ radical could attack the membranes and other macromolecules (Figure 2(b)). At least two A $\beta 42-$ mediated pathways are assumed.

Recently, Butterfield and colleagues advanced the Met35 theory into in vivo analysis using APP transgenic mice with V717F (Indiana) and M631L mutations corresponding to the substitution of Met35 with Leu in the $\mathrm{A} \beta$ sequence [74], which showed the prevention of oxidative damages in tissues and senile plaque in the brain. Unexpectedly, M35L mutation in mice exhibited almost no effects on memory and learning impairments in the Morris water maze [74], indicating that oxidative stress may be neither required nor sufficient for memory loss. Quite recently, Bitan and colleagues suggested that Met35 is not necessary for $A \beta$ toxicity despite its significant role in aggregation [75]. Other mechanisms in addition to Met35 will occur for the complete explanation of $A \beta 42$-induced neurotoxicity.

A relationship between $\mathrm{A} \beta$ oligomers and oxidative stress has been noted; Klein and colleagues proposed that ADDL induce long-term potentiation associated with oxidative damage in vitro [76]. Barnham and colleagues proposed that $A \beta$ generated dityrosine cross-linked dimers through oxidation of the phenolic hydroxyl group at Tyr10 under 


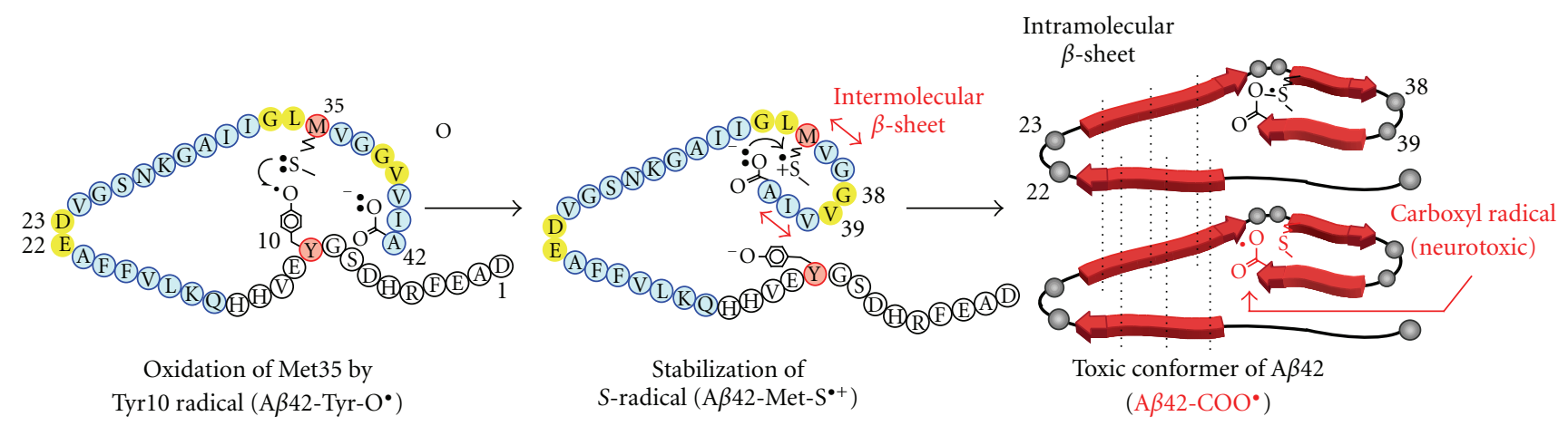

(a)

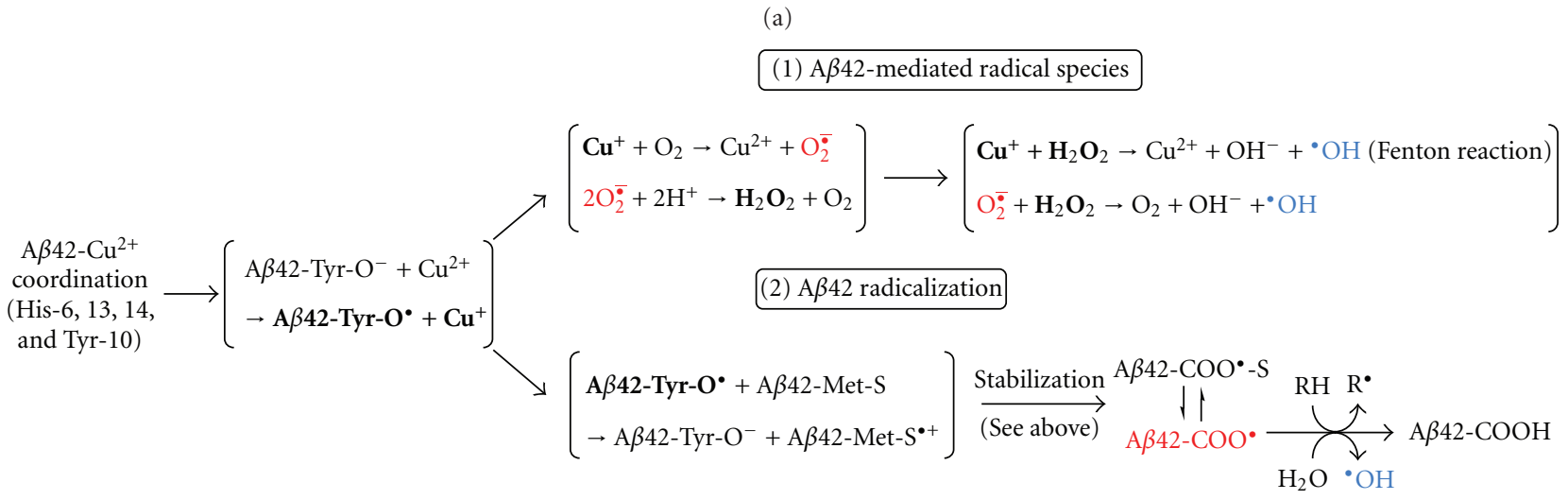

(b)

FIgURE 2: (a) Proposed mechanism of formation and stabilization of $\mathrm{A} \beta 42$ radical for long-lasting oxidative stress in $\mathrm{AD}$ and the toxic conformer of $A \beta 42$ [73]. (b) Scheme of generation of A $\beta 42$-mediated radical species (superoxide radical and hydroxyl radical) and the long-lasting $\mathrm{A} \beta 42$ radical in the pathogenesis of $\mathrm{AD}$.

oxidative conditions [55], and that generic dityrosine levels were increased in the AD brain [77]; however, it is unclear whether $\mathrm{A} \beta$-mediated oxidative damage observed in vitro is relevant to in vivo disease.

\section{Oxidative Stress and Antioxidants in Alzheimer's Disease}

There is increasing evidence that oxidative stress is a prominent and early feature of $\mathrm{AD}$ [78]. The Fenton reaction mediated by iron or copper can result in the oxidative damage of nucleic acids. Smith and colleagues proposed that 8-OHdG is an established marker of nuclear DNA oxidation for AD pathology [78]. Butterfield and colleagues proposed that $\mathrm{HNE}$ is produced by $\mathrm{A} \beta$-induced lipid peroxidation [79]. Redox proteomics using human AD brains showed that the elevation of TBARS was associated with the numbers of neuritic but not diffuse plaques [80].

On the other hand, glutathione (GSH), a tripeptide, is biosynthesized in the cytoplasm and normally exists in the mitochondrial matrix as a reduced form [81] because glutathione reductase (GR) plays a role in maintaining the ratio of GSH to GSSG through the oxidation of nicotinamide adenine dinucleotide phosphate (NADPH) (Figure 1). GSH maintains the integrity of the plasma membrane and adenosine triphosphate (ATP) in the synaptosomes as an antioxidant. Under severe oxidative stress, the accumulation of GSSG occurs together with protein modification. Studies using $\mathrm{AD}$ brains by Balaz and Leon revealed almost no changes in the levels of glutathione and catalase [82], which is an important enzyme to convert $\mathrm{H}_{2} \mathrm{O}_{2}$ into $\mathrm{H}_{2} \mathrm{O}$ and $\mathrm{O}_{2}$ (Figure 1). In contrast, Gsell et al. reported the decreased activity of catalase in AD brains [83]. Some markers of oxidative stress will be vulnerable or not to the formation of $\mathrm{A} \beta$ radical in $\mathrm{AD}$ pathology. Alternatively, the technical artifact during the isolation of proteins may affect the results for oxidative levels among different research groups.

Table 1 summarizes in vivo studies on the involvement of these enzymes in AD. The cytochrome $c$ oxidase (COX) is involved in respiratory electron transport in the mitochondrial inner membrane. There are several studies on the correlation of the reduced activity of COX and increased oxidative stress in AD brains [93, 94]. Fukui et al. crossed an $\mathrm{AD}$ transgenic mouse with a neuron-specific COX10 knockout mouse and reported that COX deficiency failed to increase both senile plaques and oxidative damage in $\mathrm{AD}$ progression in contrast to their expectations [90]. NADPH oxidase, believed to be one of the major ROS sources in the brain, participates in the generation of superoxide radical by transferring electrons across the membrane into molecular oxygen [95]. Genetic inactivation of Nox2, an isozyme of the catalytic subunit of NADPH oxidase, prevented oxidative 
TABLE 1: Studies on involvement of oxidative stress in $\mathrm{AD}$ in vivo.

\begin{tabular}{|c|c|c|c|c|c|}
\hline Objected mice & APP mice & Behavior & $\begin{array}{l}\mathrm{A} \beta \text {-dependent } \\
\text { pathology }\end{array}$ & ROS marker & References \\
\hline CuZn-SOD KO & $\operatorname{Tg} 2576$ & Early memory loss & Oligomer $\uparrow$, P-tau $\uparrow$ & $\begin{array}{l}\text { 8-OHdG } \uparrow \text {, Protein } \\
\text { carbonyls } \uparrow\end{array}$ & Submitted \\
\hline CuZn-SOD Tga & $\operatorname{Tg} 1130 \mathrm{H}$ & NT & Cerebral dysfunction $\downarrow$ & NT & {$[84]^{\mathrm{a}}$} \\
\hline Mn-SOD hetero KO & $\begin{array}{l}\operatorname{Tg} 2576^{\mathrm{b}}, \mathrm{J} 20^{\mathrm{c}} \\
\operatorname{Tg} 19959^{\mathrm{d}}\end{array}$ & Early memory loss ${ }^{\mathrm{c}}$ & $\begin{array}{l}\mathrm{A} \beta \text { depositions } \uparrow^{\mathrm{c}, \mathrm{d}}, \\
\mathrm{P}-\operatorname{tau} \uparrow^{\mathrm{b}}\end{array}$ & NT & {$[85]^{\mathrm{b}},[86]^{\mathrm{c}},[87]^{\mathrm{d}}$} \\
\hline Mn-SOD Tg & $\operatorname{Tg} 2576^{\mathrm{e}}, \operatorname{Tg} 19959^{\mathrm{f}}$ & $\begin{array}{l}\text { Improved memory } \\
\text { loss }^{\mathrm{e}, \mathrm{f}}\end{array}$ & $\begin{array}{l}\mathrm{A} \beta 42 / \mathrm{A} \beta 40 \downarrow^{\mathrm{e}} \\
\text { Plaque } \downarrow^{\mathrm{f}}\end{array}$ & $\begin{array}{l}\mathrm{DHE} \downarrow^{\mathrm{e}}, \text { Catalase } \uparrow^{\mathrm{f}}, \\
\text { Protein carbonyls } \downarrow^{\mathrm{f}} \text {, }\end{array}$ & {$[88]^{\mathrm{e}},[89]^{\mathrm{f}}$} \\
\hline COX10 KO & APPswe/PSEN1 $\triangle \mathrm{E} 9$ & NT & Plaque $\downarrow, A \beta 42 \downarrow$ & $\begin{array}{l}\text { 8-OHdG } \downarrow \text {, Protein } \\
\text { carbonyls } \downarrow\end{array}$ & {$[90]$} \\
\hline Nox2 KO & $\operatorname{Tg} 2576$ & $\begin{array}{c}\text { Improved } \\
\text { abnormal behavior }\end{array}$ & $\begin{array}{l}\text { Unchanged (A } \beta 42 \text {, } \\
\mathrm{A} \beta 42, \text { plaque) }\end{array}$ & DHE $\downarrow$ & {$[91]$} \\
\hline $\begin{array}{l}\alpha \text {-tocophenol transfer } \\
\text { protein KO }\end{array}$ & $\operatorname{Tg} 2576$ & NT & $\mathrm{A} \beta 40 \uparrow, \mathrm{IDE} \downarrow$ & Unchanged & {$[92]$} \\
\hline
\end{tabular}

Abbreviations: $\mathrm{A} \beta$, amyloid $\beta$; $\mathrm{AD}$, Alzheimer's disease; $\mathrm{APP}$, amyloid precursor protein; $\mathrm{COX}$, cytochrome $c$ oxidase; DHE, dihydroethidium; IDE, insulindegrading enzyme; KO, knock out; Nox, NADPH oxidase; NT, not tested; 8-OHdG, 8-hydroxydeoxyguanosine; PSEN, presenilin; P-tau, phosphorylated tau; ROS, reactive oxygen species; SOD, superoxide dismutase; Tg, transgenic; $\uparrow$, increased; $\downarrow$, decreased.

stress, $\mathrm{A} \beta$-derived neurovascular dysfunction, and behavioral impairment without affecting $\mathrm{A} \beta$ assembly [91]. Binding of the transcription factor nuclear factor E2-related factor 2 (Nrf2) to the antioxidant response element (ARE) enhancer sequence is known to induce the endogenous defense system against oxidative stress. The Nrf2-ARE pathway is activated in response to ROS, triggering the expression of antioxidant enzymes. Kanninen et al. reported that intrahippocampal injection of Nrf2 mitigated the spatial impairment of $\mathrm{AD}$ mice (APP/PS1 mice) associated with increased plaque formation and heme oxygenase-1 levels [96].

Glutathione peroxidase (GPx) is also a key modulator in the neuronal system, participating in the elimination of $\mathrm{H}_{2} \mathrm{O}_{2}$. Overexpression of GPx4, an isoform expressed in the membrane, reduced the lipid peroxidation of mice after exposure to diquat, known as a herbicide, and induced mice resistant to apoptosis from oxidants [97]. Embryonic fibroblasts of catalase transgenic mice are more resistant to toxic $\mathrm{H}_{2} \mathrm{O}_{2}$ [98]. Thioredoxin plays a role in repairing the oxidation of cysteine residues in proteins [99]. Yodoi and colleagues generated transgenic mice overexpressing human thioredoxin, which reduced oxidative stress and extended its lifespan [100]. The therapeutic effects of these antioxidative enzymes against $\mathrm{AD}$ are expected although no studies on their role in $\mathrm{AD}$ pathology have been reported.

\section{Therapeutic Role of Superoxide Dismutase in Alzheimer's Disease}

The role of $\mathrm{SOD}$ in $\mathrm{AD}$ pathogenesis has long been controversial. Several studies have shown decreased SOD in the frontal cortex of $\mathrm{AD}$ patients [101] whereas a slight elevation of SOD was documented in the caudate nucleus of $\mathrm{AD}$ patients [102]. Alternatively, other researchers have suggested that almost no changes in SOD levels are found in AD brains [83]. Quite recently, Ansari and Scheff reported a strong correlation between several oxidative damage levels using various dementia subjects with negligible levels of premortem hypoxia in order to eliminate the possibility of affecting protein integrity [103]. As shown in Table 1, Melov et al. suggested that mitochondrial oxidative stress could induce the hyperphosphorylation of tau at Ser396 using Tg2576 transgenic AD mouse model [85]. There have also been reports on the role of $\mathrm{Mn}-\mathrm{SOD}$ in $\mathrm{AD}$ pathology; AD transgenic mouse models crossed with Sod2 $2^{+/-}$resulted in increased accelerated behavioral deficits [86] or senile plaques [87] (Table 1). Quite recently, our group proposed the involvement of CuZn-SOD in $\mathrm{AD}$ progression; the superoxide radical in the cytoplasma induced $\mathrm{A} \beta$ oligomerization and early cognitive impairment in Tg2576, and these phenomena notably preceded oxidative damage (Murakami, K. et al., submitted) (Table 1). Our findings do not contradict the implication by Marlatt et al. that oxidative damage occurs primarily within the cytoplasm rather than the mitochondria [3].

In the therapy of $\mathrm{AD}$ by SODs, cerebral endothelial dysfunction in the $\mathrm{AD}$ mouse model can be improved by overexpression of Sod1 [84] (Table 1) or the administration of SOD [104]. Bayer et al. proposed that dietary intake of $\mathrm{Cu}$ stabilizes CuZn-SOD activity and decreases $\mathrm{A} \beta$ production in the APP transgenic mouse model [105]. On the other hand, overexpression of Sod 2 rescued several markers for oxidative stress associated with $\mathrm{AD}$-like pathologies in two representative lines of $\mathrm{AD}$ model mice (Tg2576 [88] and Tg19959 [89]) (Table 1). Under the excessive reduced redoxacitve metal ions, the adverse effects due to hydroxyl radical formation should be taken into account. The therapeutic treatment of both SOD and catalase mimetics (e.g., EUK-8 [106]) could be one of promising approaches.

Breteler and colleagues performed a clinical survey of the dietary intake of antioxidants and the risk of $\mathrm{AD}$ based on over 5,000 participants in the Netherlands [107]. It was suggested that high dietary intake of vitamin $C$ and vitamin $\mathrm{E}$ might lower the risk of $\mathrm{AD}$. Dementia control by 
vitamin C and vitamin E has long been discussed [108-112]. Interestingly, Rinaldi et al. suggested the correlation of vitamin C and SOD levels with the dementia status [113]. SOD might be one of the most vulnerable indicators as an antioxidant enzyme in $\mathrm{AD}$ and cognitive dementia. Alternatively, it was reported that environmental enrichment prevented AD-like pathology associated with elevated $\mathrm{CuZn-}$ SOD and Mn-SOD levels [114].

\section{Conclusions}

One of the most accepted knowledge in the etiology of AD is thought to be the free-radical theory; however, it remains to be determined whether oxidative stress is a cause or effect in $\mathrm{AD}$. A $\beta 42$ aggregates (oligomerizes) induce neurotoxins by interacting with trace metals at Tyr10 or in the $\mathrm{N}$ terminal region, leading to tissue oxidation by an $S$-oxidized radical cation in Met35. There are three means of defense from $\mathrm{A} \beta 42$-dependent $\mathrm{AD}$ pathology: (1) to slow the rate of $A \beta 42$ aggregation, (2) to decrease the production of $\mathrm{A} \beta 42$ by downregulating the activity of $\beta$ - or $\gamma$-secretase, and (3) to enhance protease activity (such as neprilysin [115], an insulin-degrading enzyme [116]) against $\mathrm{A} \beta 42$. Oxidative stress may affect one or all of the protective mechanisms. Antioxidant enzymes including SOD or dietary supplements of vitamin $\mathrm{C}$ and vitamin $\mathrm{E}$ could counteract these dysfunctions. Food treatments for prevention are a better choice to maintain the quality of life. There are increasing reports on the inhibitory effects of natural products such as several flavonoids [117], vitamin A [118], and vitamin $\mathrm{E}$ [119] on AD pathology in vivo. Nishida et al. reported $\alpha$-tocophenol transfer protein-knockout mice, in which $\mathrm{A} \beta$ deposits accumulated by decreasing the clearance of $\mathrm{A} \beta$ peptide from the brain and blood [92] (Table 1). Quite recently, we discovered the potential of silymarin [120], the active ingredient of milk thistle extract which is long used as a hepatoprotective medicine, and vitamin $\mathrm{C}$ (Murakami, K. et al., submitted) for AD prevention. Further research on structural analysis of the inhibitory mechanism is under investigation to effectively develop inhibitors with few adverse effects.

\section{Acknowledgments}

This work was supported in part by Grants-in-Aid for Scientific Research, the Program for the Promotion of Basic Research Activities for Innovative Biosciences, and funds for the Promotion of Science for Young Scientists from The Ministry of Education, Culture, Sports, Science, and Technology of the Japanese Government.

\section{References}

[1] D. Harman, "Aging: a theory based on free radical and radiation chemistry," Journal of Gerontology, vol. 11, no. 3, pp. 298-300, 1956.

[2] J. K. Andersen, "Oxidative stress in neurodegeneration: cause or consequence?” Nature Medicine, vol. 10, pp. S18-S25, 2004.
[3] M. Marlatt, H. G. Lee, G. Perry, M. A. Smith, and X. Zhu, "Sources and mechanisms of cytoplasmic oxidative damage in Alzheimer's disease," Acta Neurobiologiae Experimentalis, vol. 64, no. 1, pp. 81-87, 2004.

[4] B. Chance, H. Sies, and A. Boveris, "Hydroperoxide metabolism in mammalian organs," Physiological Reviews, vol. 59, no. 3, pp. 527-605, 1979.

[5] D. C. Wallace and S. Melov, "Radicals r'aging," Nature Genetics, vol. 19, no. 2, pp. 105-106, 1998.

[6] J. S. Valentine, P. A. Doucette, and S. Z. Potter, "Copperzinc superoxide dismutase and amyotrophic lateral sclerosis," Annual Review of Biochemistry, vol. 74, pp. 563-593, 2005.

[7] S. Elchuri, T. D. Oberley, W. Qi et al., "CuZnSOD deficiency leads to persistent and widespread oxidative damage and hepatocarcinogenesis later in life," Oncogene, vol. 24, no. 3, pp. 367-380, 2005.

[8] F. L. Muller, W. Song, Y. Liu et al., "Absence of CuZn superoxide dismutase leads to elevated oxidative stress and acceleration of age-dependent skeletal muscle atrophy," Free Radical Biology and Medicine, vol. 40, no. 11, pp. 1993-2004, 2006.

[9] H. Van Remmen and D. P. Jones, "Current thoughts on the role of mitochondria and free radicals in the biology of aging," Journals of Gerontology A, vol. 64, no. 2, pp. 171-174, 2009.

[10] Y. Iuchi, F. Okada, K. Onuma et al., "Elevated oxidative stress in erythrocytes due to a SOD1 deficiency causes anaemia and triggers autoantibody production," Biochemical Journal, vol. 402, no. 2, pp. 219-227, 2007.

[11] K. Murakami, J. Inagaki, M. Saito et al., "Skin atrophy in cytoplasmic SOD-deficient mice and its complete recovery using a vitamin C derivative," Biochemical and Biophysical Research Communications, vol. 382, no. 2, pp. 457-461, 2009.

[12] Y. Imamura, S. Noda, K. Hashizume et al., "Drusen, choroidal neovascularization, and retinal pigment epithelium dysfunction in SOD1-deficient mice: a model of agerelated macular degeneration," Proceedings of the National Academy of Sciences of the United States of America, vol. 103, no. 30, pp. 11282-11287, 2006.

[13] S. Uchiyama, T. Shimizu, and T. Shirasawa, "CuZn-SOD deficiency causes ApoB degradation and induces hepatic lipid accumulation by impaired lipoprotein secretion in mice," Journal of Biological Chemistry, vol. 281, no. 42, pp. 3171331719, 2006.

[14] Y. Li, T. T. Huang, E. J. Carlson et al., "Dilated cardiomyopathy and neonatal lethality in mutant mice lacking manganese superoxide dismutase," Nature Genetics, vol. 11, no. 4, pp. 376-381, 1995.

[15] R. M. Lebovitz, H. Zhang, H. Vogel et al., "Neurodegeneration, myocardial injury, and perinatal death in mitochondrial superoxide dismutase-deficient mice," Proceedings of the National Academy of Sciences of the United States of America, vol. 93, no. 18, pp. 9782-9787, 1996.

[16] T. Ikegami, Y. Suzuki, T. Shimizu, K. Isono, H. Koseki, and T. Shirasawa, "Model mice for tissue-specific deletion of the manganese superoxide dismutase (MnSOD) gene," Biochemical and Biophysical Research Communications, vol. 296, no. 3, pp. 729-736, 2002.

[17] H. Nojiri, T. Shimizu, M. Funakoshi et al., "Oxidative stress causes heart failure with impaired mitochondrial respiration," Journal of Biological Chemistry, vol. 281, no. 44, pp. 33789-33801, 2006. 
[18] H. Kuwahara, T. Horie, S. Ishikawa et al., "Oxidative stress in skeletal muscle causes severe disturbance of exercise activity without muscle atrophy," Free Radical Biology and Medicine, vol. 48, no. 9, pp. 1252-1262, 2010.

[19] T. Shimizu, H. Nojiri, S. Kawakami, S. Uchiyama, and T. Shirasawa, "Model mice for tissue-specific deletion of the manganese superoxide dismutase gene," Geriatrics and Gerontology International, vol. 10, supplement 1, pp. S70S79, 2010.

[20] R. Resende, P. I. Moreira, T. Proença et al., "Brain oxidative stress in a triple-transgenic mouse model of Alzheimer disease," Free Radical Biology and Medicine, vol. 44, no. 12, pp. 2051-2057, 2008.

[21] G. G. Glenner and C. W. Wong, "Alzheimer's disease: initial report of the purification and characterization of a novel cerebrovascular amyloid protein," Biochemical and Biophysical Research Communications, vol. 120, no. 3, pp. 885-890, 1984.

[22] C. L. Masters, G. Simms, and N. A. Weinman, "Amyloid plaque core protein in Alzheimer disease and Down syndrome," Proceedings of the National Academy of Sciences of the United States of America, vol. 82, no. 12, pp. 4245-4249, 1985.

[23] C. Haass and D. J. Selkoe, "Soluble protein oligomers in neurodegeneration: lessons from the Alzheimer's amyloid $\beta$ peptide," Nature Reviews Molecular Cell Biology, vol. 8, no. 2, pp. 101-112, 2007.

[24] D. M. Walsh, I. Klyubin, J. V. Fadeeva et al., "Naturally secreted oligomers of amyloid $\beta$ protein potently inhibit hippocampal long-term potentiation in vivo," Nature, vol. 416, no. 6880, pp. 535-539, 2002.

[25] H. G. Lee, X. Zhu, R. J. Castellani, A. Nunomura, G. Perry, and M. A. Smith, "Amyloid- $\beta$ in Alzheimer disease: the null versus the alternate hypotheses," Journal of Pharmacology and Experimental Therapeutics, vol. 321, no. 3, pp. 823-829, 2007.

[26] T. Gómez-Isla, R. Hollister, H. West et al., "Neuronal loss correlates with but exceeds neurofibrillary tangles in Alzheimer's disease," Annals of Neurology, vol. 41, no. 1, pp. 17-24, 1997.

[27] M. Meyer-Luehmann, T. L. Spires-Jones, C. Prada et al., "Rapid appearance and local toxicity of amyloid- $\beta$ plaques in a mouse model of Alzheimer's disease," Nature, vol. 451, no. 7179, pp. 720-724, 2008.

[28] R. Roychaudhuri, M. Yang, M. M. Hoshi, and D. B. Teplow, "Amyloid $\beta$-protein assembly and Alzheimer disease," Journal of Biological Chemistry, vol. 284, no. 8, pp. 4749-4753, 2009.

[29] J. D. Harper, S. S. Wong, C. M. Lieber, and P. T. Lansbury, "Observation of metastable A $\beta$ amyloid protofibrils by atomic force microscopy," Chemistry and Biology, vol. 4, no. 2, pp. 119-125, 1997.

[30] W. L. Klein, G. A. Krafft, and C. E. Finch, "Targeting small A $\beta$ oligomers: the solution to an Alzheimer's disease conundrum?" Trends in Neurosciences, vol. 24, no. 4, pp. 219224, 2001.

[31] S. Lesné, T. K. Ming, L. Kotilinek et al., "A specific amyloid- $\beta$ protein assembly in the brain impairs memory," Nature, vol. 440, no. 7082, pp. 352-357, 2006.

[32] M. Hoshi, M. Sato, S. Matsumoto et al., "Spherical aggregates of $\beta$-amyloid (amylospheroid) show high neurotoxicity and activate tau protein kinase I/glycogen synthase kinase-3 $\beta$," Proceedings of the National Academy of Sciences of the United States of America, vol. 100, no. 11, pp. 6370-6375, 2003.

[33] G. M. Shankar, S. Li, T. H. Mehta et al., "Amyloid- $\beta$ protein dimers isolated directly from Alzheimer's brains impair synaptic plasticity and memory," Nature Medicine, vol. 14, no. 8, pp. 837-842, 2008.

[34] W. Xia, T. Yang, G. Shankar et al., "A specific enzyme-linked immunosorbent assay for measuring $\beta$-amyloid protein oligomers in human plasma and brain tissue of patients with Alzheimer Disease," Archives of Neurology, vol. 66, no. 2, pp. 190-199, 2009.

[35] G. Bitan and D. B. Teplow, "Rapid photochemical crosslinking - a new tool for studies of metastable, amyloidogenic protein assemblies," Accounts of Chemical Research, vol. 37, no. 6, pp. 357-364, 2004.

[36] R. Kayed, E. Head, J. L. Thompson et al., "Common structure of soluble amyloid oligomers implies common mechanism of pathogenesis," Science, vol. 300, no. 5618, pp. 486-489, 2003.

[37] R. Kayed, E. Head, F. Sarsoza et al., "Fibril specific, conformation dependent antibodies recognize a generic epitope common to amyloid fibrils and fibrillar oligomers that is absent in prefibrillar oligomers," Molecular Neurodegeneration, vol. 2, no. 1, p. 18, 2007.

[38] R. D. Terry and C. Pena, "Experimental production of neurofibrillary degeneration 2 . electron microscopy, phosphatase histochemistry and electron probe analysis," Journal of Neuropathology and Experimental Neurology, vol. 24, pp. 200-210, 1965.

[39] V. Frisardi, V. Solfrizzi, C. Capurso et al., "Aluminum in the diet and alzheimer's disease: from current epidemiology to possible disease-modifying treatment," Journal of Alzheimer's Disease, vol. 20, no. 1, pp. 17-30, 2010.

[40] W. D. Ehmann, W. R. Markesbery, and M. Alauddin, "Brain trace elements in Alzheimer's disease," NeuroToxicology, vol. 7, no. 1, pp. 197-206, 1986.

[41] A. I. Bush, "The metallobiology of Alzheimer's disease," Trends in Neurosciences, vol. 26, no. 4, pp. 207-214, 2003.

[42] K. J. Barnham, C. L. Masters, and A. I. Bush, "Neurodegenerative diseases and oxidatives stress," Nature Reviews Drug Discovery, vol. 3, no. 3, pp. 205-214, 2004.

[43] D. A. Butterfield, "Amyloid $\beta$-peptide [1-42]-assosiated free radical-induced oxidative stress and neurodegeneration in Alzheimer's disease brain: mechanisms and consequences," Current Medicinal Chemistry, vol. 10, no. 24, pp. 2651-2659, 2003.

[44] K. Hensley, N. Hall, R. Subramaniam et al., "Brain regional correspondence between Alzheimer's disease histopathology and biomarkers of protein oxidation," Journal of Neurochemistry, vol. 65, no. 5, pp. 2146-2156, 1995.

[45] T. A. Bayer, S. Schäfer, H. Breyhan, O. Wirths, C. Treiber, and G. Multhaup, "A vicious circle: role of oxidative stress, intraneuronal $\mathrm{A} \beta$ and $\mathrm{Cu}$ in Alzheimer's disease," Clinical Neuropathology, vol. 25, no. 4, pp. 163-171, 2006.

[46] X. Huang, M. P. Cuajungco, C. S. Atwood et al., "Cu(II) potentiation of Alzheimer $\mathrm{A} \beta$ neurotoxicity. Correlation with cell-free hydrogen peroxide production and metal reduction," Journal of Biological Chemistry, vol. 274, no. 52, pp. 37111-37116, 1999.

[47] J. W. Karr, L. J. Kaupp, and V. A. Szalai, "Amyloid- $\beta$ binds $\mathrm{Cu} 2+$ in a mononuclear metal ion binding site," Journal of the American Chemical Society, vol. 126, no. 41, pp. 1353413538, 2004.

[48] J. W. Karr, H. Akintoye, L. J. Kaupp, and V. A. Szalai, "Nterminal deletions modify the $\mathrm{Cu} 2+$ binding site in amyloidß," Biochemistry, vol. 44, no. 14, pp. 5478-5487, 2005. 
[49] C. C. Curtain, F. Ali, I. Volitakis et al., "Alzheimer's disease amyloid- $\beta$ binds Copper and Zinc to generate an allosterically ordered membrane-penetrating structure containing superoxide dismutase-like subunits," Journal of Biological Chemistry, vol. 276, no. 23, pp. 20466-20473, 2001.

[50] C. C. Curtain, F. E. Ali, D. G. Smith, A. I. Bush, C. L. Masters, and K. J. Barnham, "Metal ions, $\mathrm{pH}$, and cholesterol regulate the interactions of Alzheimer's disease amyloid- $\beta$ peptide with membrane lipid," Journal of Biological Chemistry, vol. 278, no. 5, pp. 2977-2982, 2003.

[51] A. K. Tickler, D. G. Smith, G. D. Ciccotosto et al., "Methylation of the imidazole side chains of the Alzheimer disease amyloid- $\beta$ peptide results in abolition of superoxide dismutase-like structures and inhibition of neurotoxicity," Journal of Biological Chemistry, vol. 280, no. 14, pp. 1335513363, 2005.

[52] O. N. Antzutkin, “Amyloidosis of Alzheimer's A $\beta$ peptides: solid-state nuclear magnetic resonance, electron paramagnetic resonance, transmission electron microscopy, scanning transmission electron microscopy and atomic force microscopy studies," Magnetic Resonance in Chemistry, vol. 42, no. 2, pp. 231-246, 2004.

[53] C. D. Syme, R. C. Nadal, S. E. J. Rigby, and J. H. Viles, "Copper binding to the amyloid- $\beta(\mathrm{A} \beta)$ peptide associated with Alzheimer's disease: folding, coordination geometry, $\mathrm{pH}$ dependence, stoichiometry, and affinity of $\mathrm{A} \beta-(1-28)$ : insights from a range of complementary spectroscopic techniques," Journal of Biological Chemistry, vol. 279, no. 18, pp. 18169-18177, 2004.

[54] S. C. Drew, C. L. Masters, and K. J. Barnham, "Alanine2 carbonyl is an oxygen ligand in $\mathrm{Cu} 2+$ coordination of Alzheimer's disease amyloid- $\beta$ peptide-relevance to $\mathrm{N}$ terminally truncated forms," Journal of the American Chemical Society, vol. 131, no. 25, pp. 8760-8761, 2009.

[55] K. J. Barnham, F. Haeffner, G. D. Ciccotosto et al., "Tyrosine gated electron transfer is key to the toxic mechanism of Alzheimer's disease $\beta$-amyloid," FASEB Journal, vol. 18, no. 12, pp. 1427-1429, 2004.

[56] K. Ono, M. M. Condron, and D. B. Teplow, "Effects of the English (H6R) and Tottori (D7N) familial Alzheimer disease mutations on amyloid beta-protein assembly and toxicity," Journal of Biological Chemistry, vol. 285, no. 30, pp. 2318623197, 2010.

[57] R. A. Cherny, C. S. Atwood, M. E. Xilinas et al., "Treatment with a copper-zinc chelator markedly and rapidly inhibits $\beta$-amyloid accumulation in Alzheimer's disease transgenic mice," Neuron, vol. 30, no. 3, pp. 665-676, 2001.

[58] C. Treiber, A. Simons, M. Strauss et al., "Clioquinol mediates copper uptake and counteracts copper efflux activities of the amyloid precursor protein of Alzheimer's disease," Journal of Biological Chemistry, vol. 279, no. 50, pp. 51958-51964, 2004.

[59] P. J. Crouch, K. J. Barnham, A. I. Bush, and A. R. White, "Therapeutic treatments for Alzheimer's disease based on metal bioavailability," Drug News and Perspectives, vol. 19, no. 8, pp. 469-474, 2006.

[60] P. A. Adlard, R. A. Cherny, D. I. Finkelstein et al., "Rapid restoration of cognition in alzheimer's transgenic mice with 8 -Hydroxy quinoline analogs is associated with decreased interstitial A $\beta$," Neuron, vol. 59, no. 1, pp. 43-55, 2008.

[61] L. Lannfelt, K. Blennow, H. Zetterberg et al., "Safety, efficacy, and biomarker findings of PBT2 in targeting A $\beta$ as a modifying therapy for Alzheimer's disease: a phase IIa, double-blind, randomised, placebo-controlled trial," The Lancet Neurology, vol. 7, no. 9, pp. 779-786, 2008.
[62] S. Varadarajan, S. Yatin, J. Kanski, F. Jahanshahi, and D. A. Butterfield, "Methionine residue 35 is important in amyloid $\beta$-peptide-associated free radical oxidative stress," Brain Research Bulletin, vol. 50, no. 2, pp. 133-141, 1999.

[63] J. Naslund, A. Schierhorn, U. Hellman et al., "Relative abundance of Alzheimer $\mathrm{A} \beta$ amyloid peptide variants in Alzheimer disease and normal aging," Proceedings of the National Academy of Sciences of the United States of America, vol. 91, no. 18, pp. 8378-8382, 1994.

[64] Y. M. Kuo, T. A. Kokjohn, T. G. Beach et al., "Comparative analysis of amyloid-beta chemical structure and amyloid plaque morphology of transgenic mouse and Alzheimer's disease brains," Journal of Biological Chemistry, vol. 276, no. 16, pp. 12991-12998, 2001.

[65] R. Pal, D. B. Oien, F. Y. Ersen, and J. Moskovitz, "Elevated levels of brain-pathologies associated with neurodegenerative diseases in the methionine sulfoxide reductase A knockout mouse," Experimental Brain Research, vol. 180, no. 4, pp. 765774, 2007.

[66] S. Varadarajan, J. Kanski, M. Aksenova, C. Lauderback, and D. A. Butterfield, "Different mechanisms of oxidative stress and neurotoxicity for Alzheimer's A $\beta(1-42)$ and A $\beta(25-35)$," Journal of the American Chemical Society, vol. 123, no. 24, pp. 5625-5631, 2001.

[67] K. Irie, K. Murakami, Y. Masuda et al., "The toxic conformation of the 42-residue amyloid $\beta$ peptide and its relevance to oxidative stress in Alzheimer's disease," Mini-Reviews in Medicinal Chemistry, vol. 7, no. 10, pp. 1001-1008, 2007.

[68] K. Murakami, Y. Masuda, T. Shirasawa, T. Shimizu, and K. Irie, "The turn formation at positions 22 and 23 in the 42-mer amyloid beta peptide: the emerging role in the pathogenesis of Alzheimer's disease," Geriatrics and Gerontology International, vol. 10, supplement 1, pp. S169S179, 2010

[69] Y. Masuda, S. Uemura, R. Ohashi et al., "Identification of physiological and toxic conformations in A $\beta 42$ aggregates," Chembiochem, vol. 10, no. 2, pp. 287-295, 2009.

[70] K. Murakami, Y. Horikoshi-Sakuraba, N. Murata et al., "Monoclonal antibody against the turn of the 42-residue amyloid beta protein at positions 22 and 23," ACS Chemical Neuroscience, vol. 1, no. 11, pp. 747-756, 2010.

[71] A. Morimoto, K. Irie, K. Murakami et al., "Analysis of the secondary structure of beta-amyloid (Abeta42) fibrils by systematic proline replacement," Journal of Biological Chemistry, vol. 279, no. 50, pp. 52781-52788, 2004.

[72] J. Kanski, M. Aksenova, C. Schöneich, and D. A. Butterfield, "Substitution of isoleucine-31 by helical-breaking proline abolishes oxidative stress and neurotoxic properties of Alzheimer's amyloid $\beta$-peptide," Free Radical Biology and Medicine, vol. 32, no. 11, pp. 1205-1211, 2002.

[73] K. Murakami, K. Irie, H. Ohigashi et al., "Formation and stabilization model of the 42 -mer $\mathrm{A} \beta$ radical: implications for the long-lasting oxidative stress in Alzheimer's disease," Journal of the American Chemical Society, vol. 127, no. 43, pp. 15168-15174, 2005.

[74] D. A. Butterfield, V. Galvan, M. B. Lange et al., "In vivo oxidative stress in brain of Alzheimer disease transgenic mice: requirement for methionine 35 in amyloid $\beta$-peptide of APP," Free Radical Biology and Medicine, vol. 48, no. 1, pp. 136-144, 2010.

[75] P. Maiti, A. Lomakin, G. B. Benedek, and G. Bitan, "Despite its role in assembly, methionine 35 is not necessary for amyloid $\beta$-protein toxicity," Journal of Neurochemistry, vol. 113, no. 5, pp. 1252-1262, 2010. 
[76] F. G. De Felice, P. T. Velasco, M. P. Lambert et al., "Abeta oligomers induce neuronal oxidative stress through an $\mathrm{N}$ methyl-D-aspartate receptor-dependent mechanism that is blocked by the Alzheimer drug memantine," Journal of Biological Chemistry, vol. 282, no. 15, pp. 11590-11601, 2007.

[77] D. G. Smith, R. Cappai, and K. J. Barnham, "The redox chemistry of the Alzheimer's disease amyloid $\beta$ peptide," Biochimica et Biophysica Acta, vol. 1768, no. 8, pp. 1976-1990, 2007.

[78] A. Nunomura, G. Perry, G. Aliev et al., "Oxidative damage is the earliest event in Alzheimer disease," Journal of Neuropathology and Experimental Neurology, vol. 60, no. 8, pp. 759-767, 2001.

[79] C. M. Lauderback, J. M. Hackett, J. N. Keller et al., "Vulnerability of synaptosomes from ApoE knock-out mice to structural and oxidative modifications induced by $\mathrm{A} \beta(1-$ 40): implications for Alzheimer's disease," Biochemistry, vol. 40, no. 8, pp. 2548-2554, 2001.

[80] J. N. Keller, F. A. Schmitt, S. W. Scheff et al., "Evidence of increased oxidative damage in subjects with mild cognitive impairment," Neurology, vol. 64, no. 7, pp. 1152-1156, 2005.

[81] D. W. Starke, Y. Chen, C. P. Bapna, E. J. Lesnefsky, and J. J. Mieyal, "Sensitivity of protein sulfhydryl repair enzymes to oxidative stress," Free Radical Biology and Medicine, vol. 23, no. 3, pp. 373-384, 1997.

[82] L. Balazs and M. Leon, "Evidence of an oxidative challenge in the Alzheimer's brain," Neurochemical Research, vol. 19, no. 9, pp. 1131-1137, 1994.

[83] W. Gsell, R. Conrad, M. Hickethier et al., "Decreased catalase activity but unchanged superoxide dismutase activity in brains of patients with dementia of Alzheimer type," Journal of Neurochemistry, vol. 64, no. 3, pp. 1216-1223, 1995.

[84] C. Iadecola, F. Zhang, K. Niwa et al., "SOD1 rescues cerebral endothelial dysfunction in mice overexpressing amyloid precursor protein," Nature Neuroscience, vol. 2, no. 2, pp. 157-161, 1999.

[85] S. Melov, P. A. Adlard, K. Morten et al., "Mitochondrial oxidative stress causes hyperphosphorylation of tau," PLos One, vol. 2, no. 6, article e536, 2007.

[86] L. Esposito, J. Raber, L. Kekonius et al., "Reduction in mitochondrial superoxide dismutase modulates Alzheimer's disease-like pathology and accelerates the onset of behavioral changes in human amyloid precursor protein transgenic mice," Journal of Neuroscience, vol. 26, no. 19, pp. 5167-5179, 2006.

[87] F. Li, N. Y. Calingasan, F. Yu et al., "Increased plaque burden in brains of APP mutant MnSOD heterozygous knockout mice," Journal of Neurochemistry, vol. 89, no. 5, pp. 13081312, 2004.

[88] C. A. Massaad, T. M. Washington, R. G. Pautler, and E. Klann, "Overexpression of SOD-2 reduces hippocampal superoxide and prevents memory deficits in a mouse model of Alzheimer's disease," Proceedings of the National Academy of Sciences of the United States of America, vol. 106, no. 32, pp. 13576-13581, 2009.

[89] M. Dumont, E. Wille, C. Stack, N. Y. Calingasan, M. F. Beal, and M. T. Lin, "Reduction of oxidative stress, amyloid deposition, and memory deficit by manganese superoxide dismutase overexpression in a transgenic mouse model of Alzheimer's disease," FASEB Journal, vol. 23, no. 8, pp. 24592466, 2009.

[90] H. Fukui, F. Diaz, S. Garcia, and C. T. Moraes, "Cytochrome c oxidase deficiency in neurons decreases both oxidative stress and amyloid formation in a mouse model of Alzheimer's disease," Proceedings of the National Academy of Sciences of the United States of America, vol. 104, no. 35, pp. 14163-14168, 2007.

[91] L. Park, P. Zhou, R. Pitstick et al., "Nox2-derived radicals contribute to neurovascular and behavioral dysfunction in mice overexpressing the amyloid precursor protein," Proceedings of the National Academy of Sciences of the United States of America, vol. 105, no. 4, pp. 1347-1352, 2008.

[92] Y. Nishida, S. Ito, S. Ohtsuki et al., "Depletion of vitamin $\mathrm{E}$ increases amyloid beta accumulation by decreasing its clearances from brain and blood in a mouse model of Alzheimer disease," Journal of Biological Chemistry, vol. 284, no. 48, pp. 33400-33408, 2009.

[93] W. D. Parker, N. J. Mahr, C. M. Filley et al., "Reduced platelet cytochrome c oxidase activity in Alzheimer's disease," Neurology, vol. 44, no. 6, pp. 1086-1090, 1994.

[94] E. M. Mutisya, A. C. Bowling, and M. F. Beal, "Cortical cytochrome oxidase activity is reduced in Alzheimer's disease," Journal of Neurochemistry, vol. 63, no. 6, pp. 21792184, 1994.

[95] K. Bedard and K. H. Krause, "The NOX family of ROSgenerating NADPH oxidases: physiology and pathophysiology," Physiological Reviews, vol. 87, no. 1, pp. 245-313, 2007.

[96] K. Kanninen, R. Heikkinen, T. Malm et al., "Intrahippocampal injection of a lentiviral vector expressing Nrf2 improves spatial learning in a mouse model of Alzheimer's disease," Proceedings of the National Academy of Sciences of the United States of America, vol. 106, no. 38, pp. 16505-16510, 2009.

[97] Q. Ran, H. Liang, M. Gu et al., "Transgenic mice overexpressing glutathione peroxidase 4 are protected against oxidative stress-induced apoptosis," Journal of Biological Chemistry, vol. 279, no. 53, pp. 55137-55146, 2004.

[98] J. Mele, H. Van Remmen, J. Vijg, and A. Richardson, "Characterization of transgenic mice that overexpress both copper zinc superoxide dismutase and catalase," Antioxidants and Redox Signaling, vol. 8, no. 3-4, pp. 628-638, 2006.

[99] C. H. Lillig and A. Holmgren, "Thioredoxin and related molecules-from biology to health and disease," Antioxidants and Redox Signaling, vol. 9, no. 1, pp. 25-47, 2007.

[100] A. Mitsui, J. Hamuro, H. Nakamura et al., "Overexpression of human thioredoxin in transgenic mice controls oxidative stress and life span," Antioxidants and Redox Signaling, vol. 4, no. 4, pp. 693-696, 2002.

[101] J. S. Richardson, "Free radicals in the genesis of Alzheimer's disease," Annals of the New York Academy of Sciences, vol. 695, pp. 73-76, 1993.

[102] S. L. Marklund, R. Adolfsson, C. G. Gottfries, and B. Winblad, "Superoxide dismutase isoenzymes in normal brains and in brains from patients with dementia of Alzheimer type," Journal of the Neurological Sciences, vol. 67, no. 3, pp. 319-325, 1985.

[103] M. A. Ansari and S. W. Scheff, "Oxidative stress in the progression of alzheimer disease in the frontal cortex," Journal of Neuropathology and Experimental Neurology, vol. 69, no. 2, pp. 155-167, 2010.

[104] K. Niwa, G. A. Carlson, and C. Iadecola, "Exogenous a beta140 reproduces cerebrovascular alterations resulting from amyloid precursor protein overexpression in mice," Journal of Cerebral Blood Flow and Metabolism, vol. 20, no. 12, pp. 1659-1668, 2000.

[105] T. A. Bayer, S. Schäfer, A. Simons et al., "Dietary Cu stabilizes brain superoxide dismutase 1 activity and reduces amyloid 
Abeta production in APP23 transgenic mice," Proceedings of the National Academy of Sciences of the United States of America, vol. 100, no. 24, pp. 14187-14192, 2003.

[106] M. Baudry, S. Etienne, A. Bruce, M. Paluck, E. Jacobsen, and B. Malfroy, "Salen-manganese complexes are superoxide dismutase mimics," Biochemical and Biophysical Research Communications, vol. 192, no. 2, pp. 964-968, 1993.

[107] M. J. Engelhart, M. I. Geerlings, A. Ruitenberg et al., "Dietary intake of antioxidants and risk of Alzheimer disease," Journal of the American Medical Association, vol. 287, no. 24, pp. 3223-3229, 2002.

[108] S. Rivière, I. Birlouez-Aragon, F. Nourhashémi, and B. Vellas, "Low plasma vitamin C in Alzheimer patients despite an adequate diet," International Journal of Geriatric Psychiatry, vol. 13, no. 11, pp. 749-754, 1998.

[109] A. J. Sinclair, A. J. Bayer, J. O. Johnston, C. Warner, and S. R. J. Maxwell, "Altered plasma antioxidant status in subjects with Alzheimer's disease and vascular dementia," International Journal of Geriatric Psychiatry, vol. 13, no. 12, pp. 840-845, 1998.

[110] M. C. Morris, D. A. Evans, J. L. Bienias, C. C. Tangney, and R. S. Wilson, "Vitamin E and cognitive decline in older persons," Archives of Neurology, vol. 59, no. 7, pp. 1125-1132, 2002.

[111] M. Paleologos, R. G. Cumming, and R. Lazarus, "Cohort study of vitamin C intake and cognitive impairment," American Journal of Epidemiology, vol. 148, no. 1, pp. 45-50, 1998.

[112] I. Bourdel-Marchasson, M. C. Delmas-Beauviex, E. Peuchant et al., "Antioxidant defences and oxidative stress markers in erythrocytes and plasma from normally nourished elderly Alzheimer patients," Age and Ageing, vol. 30, no. 3, pp. 235241, 2001.

[113] P. Rinaldi, M. C. Polidori, A. Metastasio et al., "Plasma antioxidants are similarly depleted in mild cognitive impairment and in Alzheimer's disease," Neurobiology of Aging, vol. 24, no. 7, pp. 915-919, 2003.

[114] A. Herring, M. Blome, O. Ambrée, N. Sachser, W. Paulus, and K. Keyvani, "Reduction of cerebral oxidative stress following environmental enrichment in mice with alzheimerlike pathology," Brain Pathology, vol. 20, no. 1, pp. 166-175, 2010.

[115] N. Iwata, S. Tsubuki, Y. Takaki et al., "Metabolic regulation of brain A $\beta$ by neprilysin," Science, vol. 292, no. 5521, pp. 1550$1552,2001$.

[116] W. Q. Qiu, D. M. Walsh, Z. Ye et al., "Insulin-degrading enzyme regulates extracellular levels of amyloid $\beta$ - protein by degradation," Journal of Biological Chemistry, vol. 273, no. 49, pp. 32730-32738, 1998.

[117] T. Hamaguchi, K. Ono, A. Murase, and M. Yamada, "Phenolic compounds prevent Alzheimer's pathology through different effects on the amyloid-beta aggregation pathway," American Journal of Pathology, vol. 175, no. 6, pp. 2557-2565, 2009.

[118] Y. Ding, A. Qiao, Z. Wang et al., "Retinoic acid attenuates $\beta$-amyloid deposition and rescues memory deficits in an Alzheimer's disease transgenic mouse model," Journal of Neuroscience, vol. 28, no. 45, pp. 11622-11634, 2008.

[119] S. Sung, Y. Yao, K. Uryu et al., "Early vitamin E supplementation in young but not aged mice reduces Abeta levels and amyloid deposition in a transgenic model of Alzheimer's disease," The FASEB Journal, vol. 18, no. 2, pp. 323-325, 2004.
[120] N. Murata, K. Murakami, Y. Ozawa et al., "Silymarin attenuated the aAmyloid beta plaque burden and improved behavioral abnormalities in an Alzheimer's disease mouse model," Bioscience, Biotechnology and Biochemistry, vol. 74, no. 11, pp. 2299-2306, 2010. 

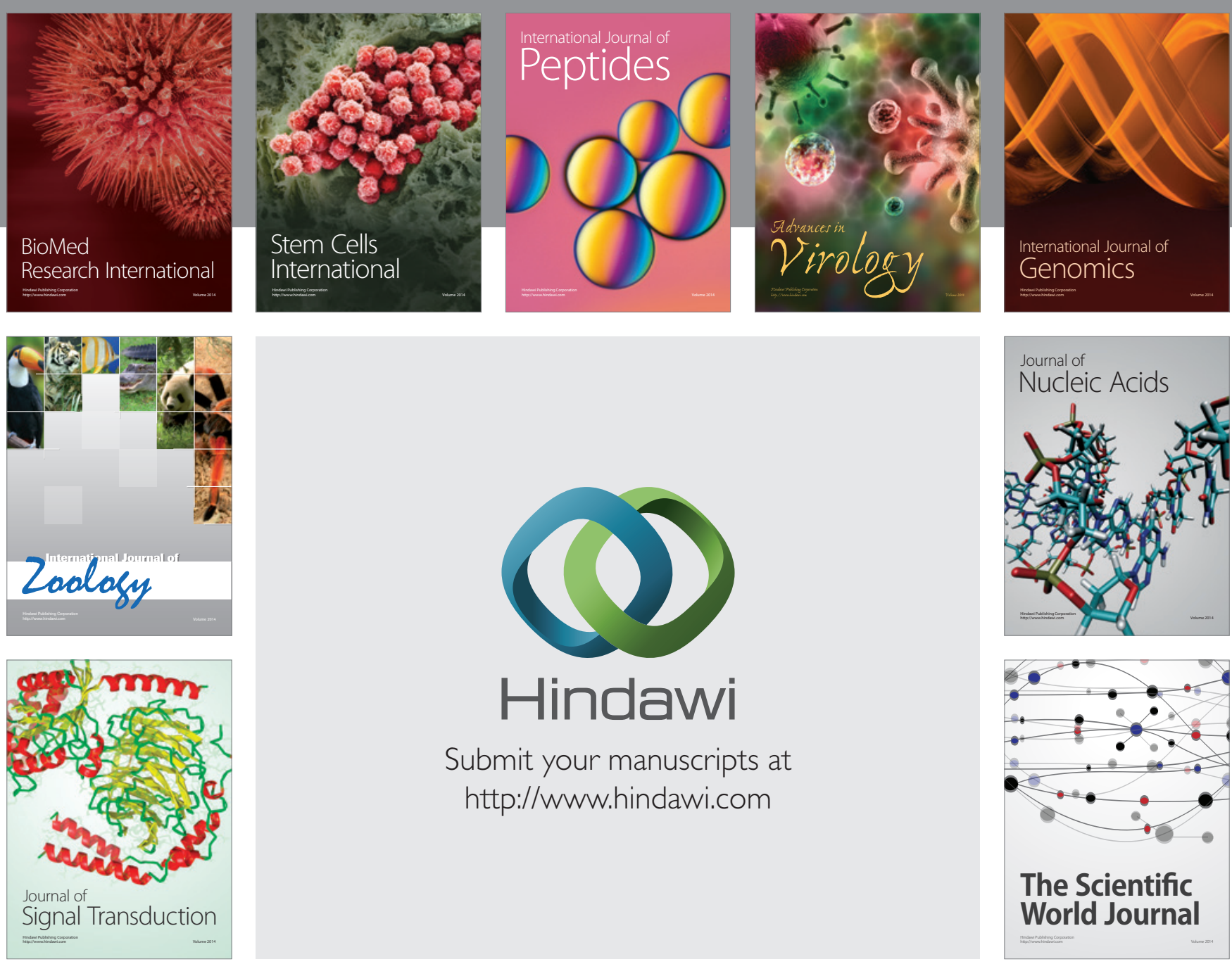

Submit your manuscripts at

http://www.hindawi.com
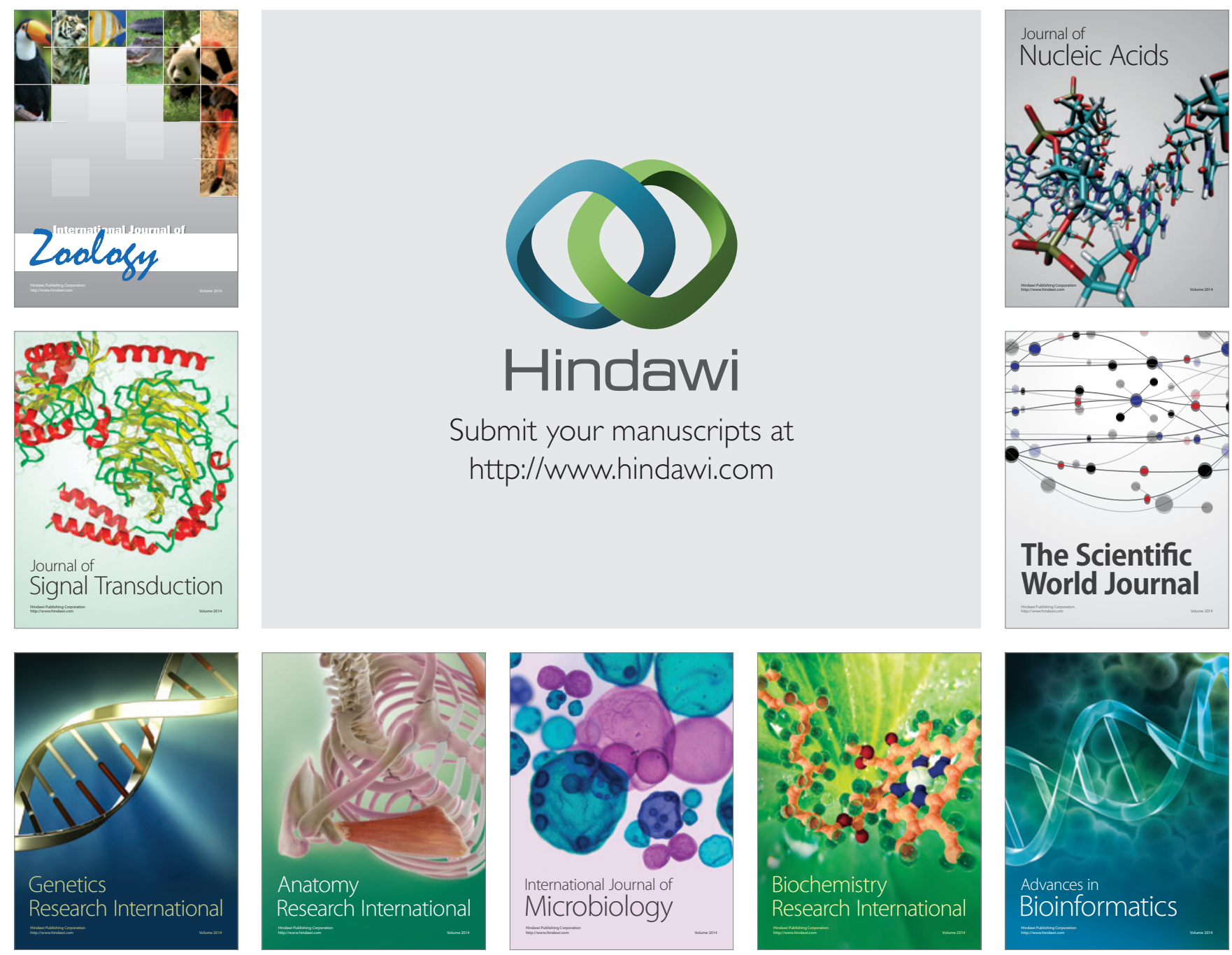

The Scientific World Journal
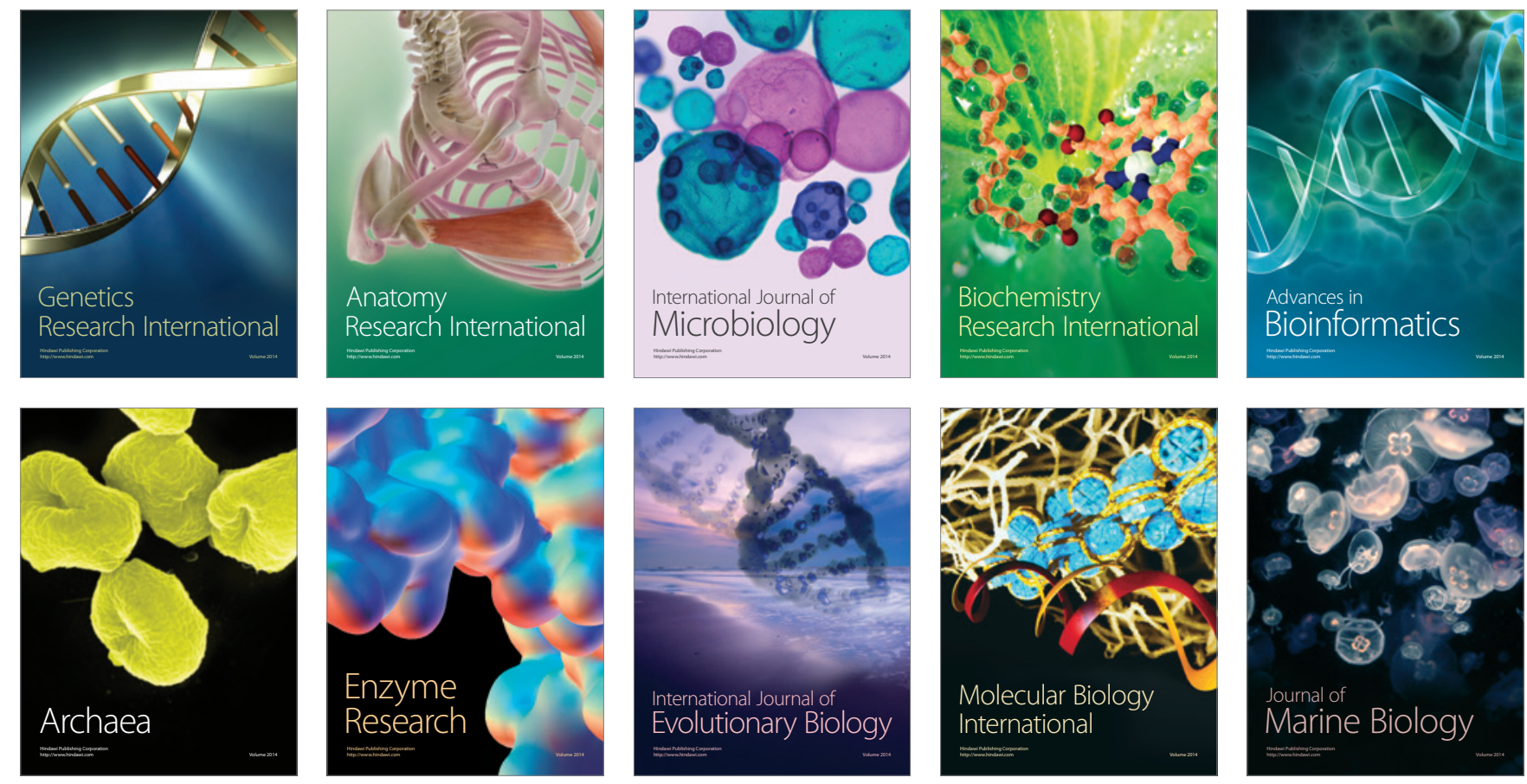